\title{
Long-Term Temperature Monitoring of a Municipal Solid Waste Landfill
}

\author{
Magdalena Vaverková*, Dana Adamcová** \\ Department of Applied and Landscape Ecology, Faculty of Agronomy, Mendel University in Brno, \\ Zemědělská 1, 61300 Brno, Czech Republic
}

Received: 27 May 2014

Accepted: 3 September 2014

\begin{abstract}
This study was conducted to investigate heat generation in a landfill on a field scale, including the variation of temperatures. Data were collected at Štěpánovice landfill in southwestern Czech Republic. Temperatures were determined over a monitoring period of 21 months. Mean annual value of the difference between outdoor temperature and temperature at a depth of $100 \mathrm{~cm}$ in the landfill body in 2012 amounted to $5.4^{\circ} \mathrm{C}$, and for the reporting period of 2013 it equailed $5.2^{\circ} \mathrm{C}$. No significant differences among measured temperatures were recorded at particular depths $(50 \mathrm{~cm}, 75 \mathrm{~cm}$, and $100 \mathrm{~cm})$. Mean temperature at the surface of the landfill within the whole reporting period was $3.2^{\circ} \mathrm{C}$ higher than ambient temperature (in the reporting period). This is explained due to the decomposition activity within the landfill site leading to the emission of warm gases. The results provide new information for the estimation of the selection of plant species suitable for reclamation, which have higher chances to tolerate the unfavorable conditions they would be exposed to a technically reclaimed landfill body.
\end{abstract}

Keywords: municipal solid waste, landfill, heat generation, temperature

\section{Introduction}

The establishment of sustainable landfills is a key strategy in modern waste management concepts. Since conventional municipal solid waste (MSW) landfills are regarded as a potential source of significant organic and inorganic emissions over long time periods [1-3], measures have to be taken to sustainably mitigate both the current and (potential) long-term emissions of the waste materials in terms of landfill gas and leachate [1].

Landfills may release environmentally harmful emissions over hundreds of years $[4,5]$. Waste in landfills converts to organic and inorganic compounds in the gaseous/liquid states by undergoing various chemical and biological transformations, leading to the formation of

*e-mail: magda.vaverkova@uake.cz

*e-mail: dana.adamcova@mendelu.cz landfill gas (LFG) and landfill leachate. These processes are generally divided into four phases. In hydrolysis, particulate material is converted to soluble compounds that are degraded to simpler acids, alcohols, and $\mathrm{CO}_{2}$ (acidogenesis). Then degradation continues to acetate and hydrogen formation (acetogenesis), and finally methane and $\mathrm{CO}_{2}$ formation (methanogenesis). The landfill temperature, moisture content/additive water amount, water characteristics (i.e., precipitation rainfall or other water entering landfills), available oxygen, and waste characteristics are among the many factors contributing to gas and leachate generation at landfill sites and subsequently determine the characteristics of LFG and landfill leachate $[4,6]$. Furthermore, the different forms of degradation are not definitive, since dynamic variations in the environmental conditions result in changes in their distribution and rates within the landfill $[4,7,8]$.

The management of landfill emissions, for both the long term and after closure, is an important and resource-inten- 
sive task. Landfills are usually operated for decades. The potential environmental risks should be understood completely in order to achieve the sustainability of landfill operational strategies. Among other factors, the landfill temperature plays a key role in determining the long-term potential of landfill emission. The actual landfill temperature may vary widely within one landfill [4].

The landfill temperature is affected by the size and height of the landfill, climatic conditions, and landfilling operations, which determine the circumstances in which microbial decomposition occurs. Understanding the impact of temperature on landfill emissions (especially landfill leachate), is significant for the improvement of long-term landfill management strategies in order to minimize landfill emissions, accelerate waste stabilization, and shorten the landfill aftercare period [4].

While various studies have been conducted on the generation and distribution of leachate and gas in landfills [914], limited information has been reported related to thermal analysis of MSW, including heat generation, ground surface temperature conditions overlying wastes, and thermal properties. In general, comprehensive long-term thermal trends are not available for landfills, nor have effects of operational or climatic conditions on heat generation in landfills been investigated.

Heat generation and temperature distributions in MSW landfills have not been commonly investigated. This study provided analysis of thermal aspects of MSW landfill using field measurements.

The objective of this study was to investigate temperature of landfill. This investigation aims to understand how environmental conditions affect the vegetation characteristics of a landfill. This knowledge may be useful in the selection of appropriate vegetation species that are adaptable to landfill environmental conditions and help improve the control of LFG emissions from a closed landfill.

\section{Experimental}

Our study was conducted at an MSW landfill in soutwestern of Czech Republic. Waste has been placed at the site since 1996, originally in controlled trenches with liner systems and leachate and gas collection and removal systems [3, 15-17]. The landfill is divided into three cells. This landfill has an authorized volume of about $569,000 \mathrm{~m}^{3}$. Its waste generation and composition is presented in other publications $[3,17]$.

All three landfill cells are equipped with a landfill leachate collection system. Landfill cells are re-circulated with landfill leachate to accelerate stabilization. After closing cell A, the landfill was covered with soil to a depth of $130 \mathrm{~cm}$, and planted over with grasses and trees. An environmental recovery and technological restoration program was constructed, and the site was reconstructed from 2008 to 2009.

Climatic and operational conditions for the landfill site investigated in this study are presented in Table 1 . The Štěpánovice landfill is located near Klatovy city (Pilsen region, Czech Republic).
Table 1. Climatic and operational conditions.

\begin{tabular}{|l|c|}
\hline \multicolumn{1}{|c|}{ Parameter } & \\
\hline Average air $\mathrm{T}\left({ }^{\circ} \mathrm{C}\right)$ & 7.1 \\
\hline Mean surface temperature $\left({ }^{\circ} \mathrm{C}\right)$ & 9.3 \\
\hline Annual normal precipitation $(\mathrm{mm})$ & 582 \\
\hline Mean annual earth temperature $\left({ }^{\circ} \mathrm{C}\right)$ & 7.4 \\
\hline Landfill body capacity $\left(10^{3} \cdot \mathrm{m}^{3}\right)$ & 569 \\
\hline Average waste intake $\left(10^{3} \mathrm{~kg} \cdot \mathrm{year}^{-1}\right)$ & 18,914 \\
\hline Primary Daily Cover & Soil \\
\hline
\end{tabular}

\section{Testing Program}

The testing program included an extensive field investigation of temperatures at MSW landfill with varying climatic conditions.

\section{Analyses}

Spatial and temporal variations of temperatures at the sites were investigated, effects of climatic and operational conditions were analyzed, and rates of temperature change also were determined.

Our aim was to measure and determine temperature differences at various depths of the landfill body $(10 \mathrm{~cm}, 50$ $\mathrm{cm}, 75 \mathrm{~cm}$, and $100 \mathrm{~cm}$ ) and outdoor temperatures in the period from January 2012 to September 2013. Temperature measurement in ${ }^{\circ} \mathrm{C}$ at different depths of the landfill body was carried out on a daily basis for a determined period of time, using a mercury thermometer manufactured by SKLO UNION Kavalier glassworks (range of the thermometer is from $-20^{\circ} \mathrm{C}$ to $+40^{\circ} \mathrm{C}$ ) and digital contact thermometer PFEUFFER (Fig. 1). Temperature was measured by outdoor sensor for temperature measurement $\mathrm{HOBO}$ (range from $-20^{\circ} \mathrm{C}$ to $+70^{\circ} \mathrm{C}$, with an accuracy of $\pm 0.7^{\circ} \mathrm{C}$, resolution $\pm 0.4^{\circ} \mathrm{C}$ ), which was placed in the area of the MSW Štěpánovice landfill scale.

\section{Results and Discussion}

Following the measurements, the results were processed and the course of daily temperatures was evaluated. Average monthly temperatures, the differences between mean monthly outdoor temperature and the temperature at a depth of $100 \mathrm{~cm}$ in the landfill body were examined, as well as the average annual outdoor Fg. 4 illustrating the difference between outdoor temperature and the temperature at $100 \mathrm{~cm}$ depth in the landfill body.

Fig. 2 shows the course of daily temperatures in the landfill body at stated depths and the course of outdoor temperature for the period January-December 2012. Daily outdoor temperatures for the period January-December 2012 show greater temperature fluctuations than daily tempera- 

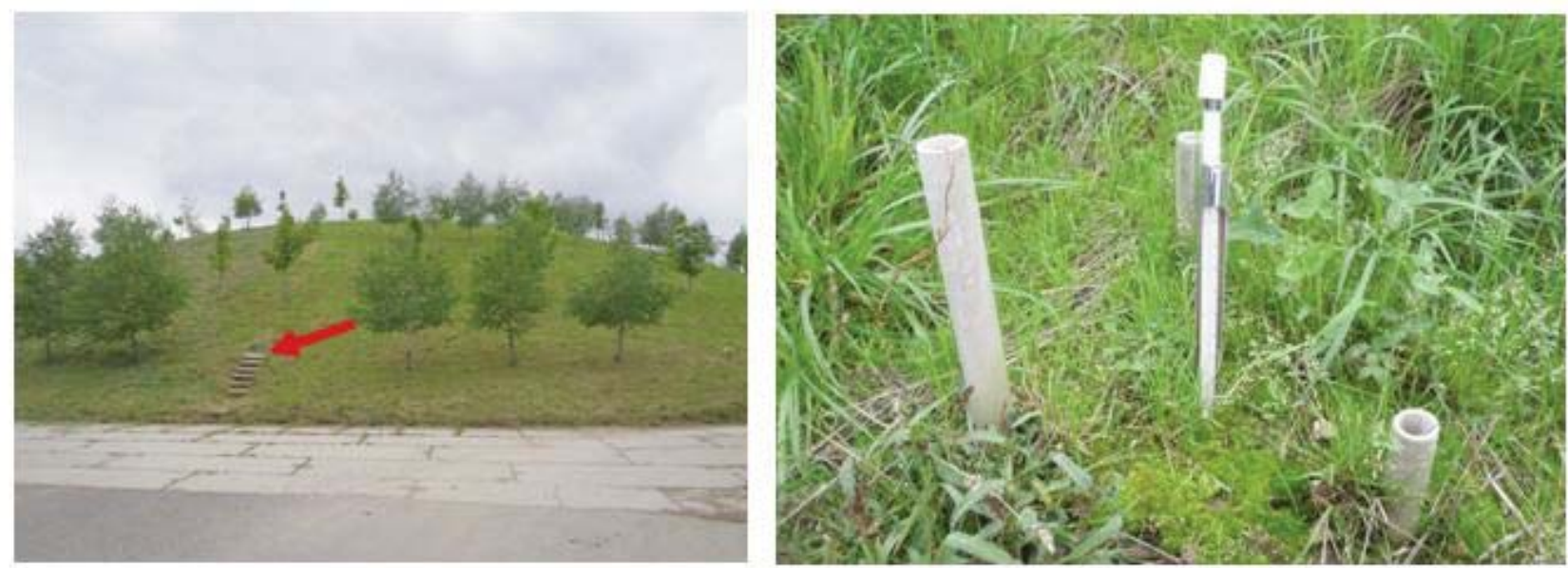

Fig. 1. Measurement location.

tures in the landfill body at depths of $50 \mathrm{~cm}, 75 \mathrm{~cm}$, and 100 $\mathrm{cm}$. The most significant oscillations of daily temperature occur at the outdoor temperatures (from $-20^{\circ} \mathrm{C}$ on 6 February 2012 to $22^{\circ} \mathrm{C}$ on 22 August 2012) and at the temperatures in the landfill body at a depth of $10 \mathrm{~cm}$ (temperatures ranged from $-7^{\circ} \mathrm{C}$ on 13 February 2012 to $20.6^{\circ} \mathrm{C}$ on 22 June 2012). As seen from Fig. 2, daily temperature in the landfill body at depths of $50 \mathrm{~cm}, 75 \mathrm{~cm}$, and $100 \mathrm{~cm}$ showed almost identical development for all three depths. No significant differences among measured temperatures were recorded in particular depths $(50 \mathrm{~cm}, 75 \mathrm{~cm}$, and 100 $\mathrm{cm})$.

Fig. 3 illustrates the development of average monthly values of measured outdoor temperatures and temperatures at stated depths of the landfill body for the period JanuaryDecember 2012. The lowest mean values were monitored at monthly temperatures measured in February 2012 (outdoor $6.2^{\circ} \mathrm{C}$, at $10 \mathrm{~cm}$ depth $-2.5^{\circ} \mathrm{C}$, at $50 \mathrm{~cm}$ depth $1.6^{\circ} \mathrm{C}$, at $75 \mathrm{~cm}$ depth $2.0^{\circ} \mathrm{C}$, and at $100 \mathrm{~cm}$ depth $1.7^{\circ} \mathrm{C}$ ). From March 2012 average temperatures were gradually increasing; the highest mean values were recorded from July to August (outdoor $14.7^{\circ} \mathrm{C}$ in July, at $10 \mathrm{~cm}$ depth $17.7^{\circ} \mathrm{C}$ in July, at $50 \mathrm{~cm}$ depth $20.0^{\circ} \mathrm{C}$ in August, at $75 \mathrm{~cm}$ depth $19.8^{\circ} \mathrm{C}$ in August, and at $100 \mathrm{~cm}$ depth $19.2^{\circ} \mathrm{C}$ in August). From August to December 2012 a decline in average monthly temperatures at all observed depths as well as in the outdoor temperature was recorded.

Higher mean monthly temperatures for all of 2012 were measured in the landfill body at depths of $50 \mathrm{~cm}$, $75 \mathrm{~cm}$, and $100 \mathrm{~cm}$. Average outdoor temperature for 2012 amounted to $5.7^{\circ} \mathrm{C}$, at $10 \mathrm{~cm}$ depth it was $8.7^{\circ} \mathrm{C}$, at $50 \mathrm{~cm}$ depth $11.4^{\circ} \mathrm{C}$, at $75 \mathrm{~cm}$ depth $11.3^{\circ} \mathrm{C}$, and at $100 \mathrm{~cm}$ depth $11.0^{\circ} \mathrm{C}$.

Based on mean monthly temperature in 2012 , the differences between outdoor temperatures and the temperatures at $100 \mathrm{~cm}$ depth of the landfill body in particular months were calculated. In addition, average annual value of the difference between outdoor temperature and the temperature at $100 \mathrm{~cm}$ depth of the landfill body was determined. The obtained results were recorded in graph (Fig. 4).

The highest mean monthly temperature in 2012 was monitored in September $\left(8.2^{\circ} \mathrm{C}\right)$ and the lowest in March $\left(2.4^{\circ} \mathrm{C}\right)$. Average annual value of the difference between outdoor temperature and the temperature at $100 \mathrm{~cm}$ depth of the landfill body in 2012 amounted to $5.4^{\circ} \mathrm{C}$.

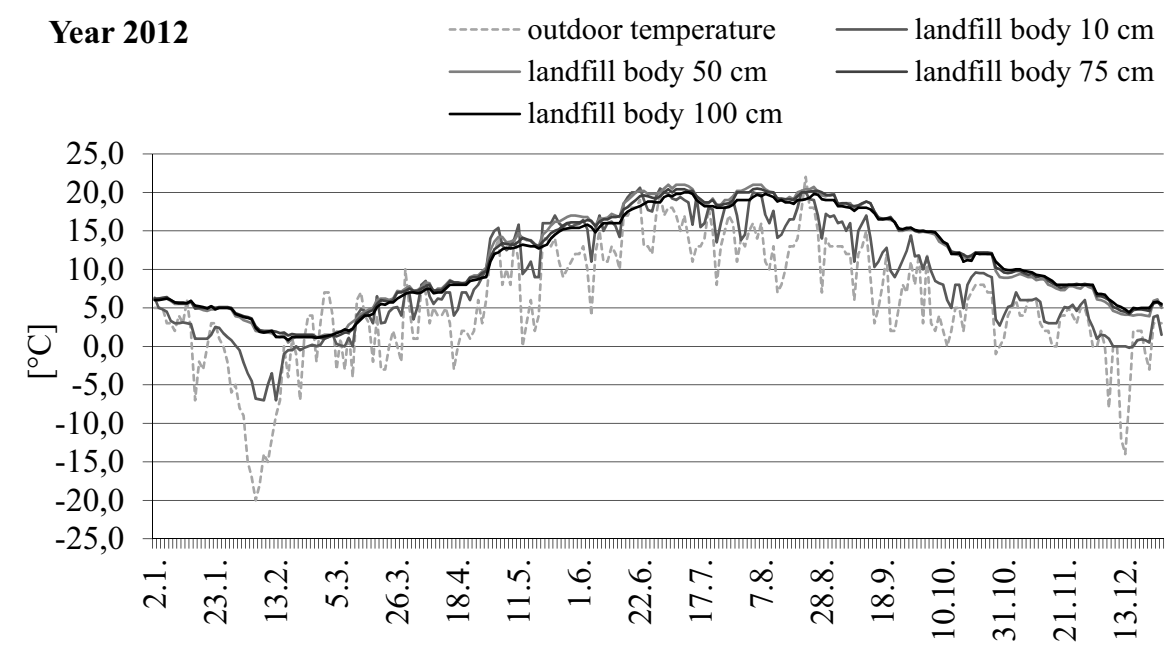

Fig. 2. The course of mean daily temperatures in the period January-December 2012. 


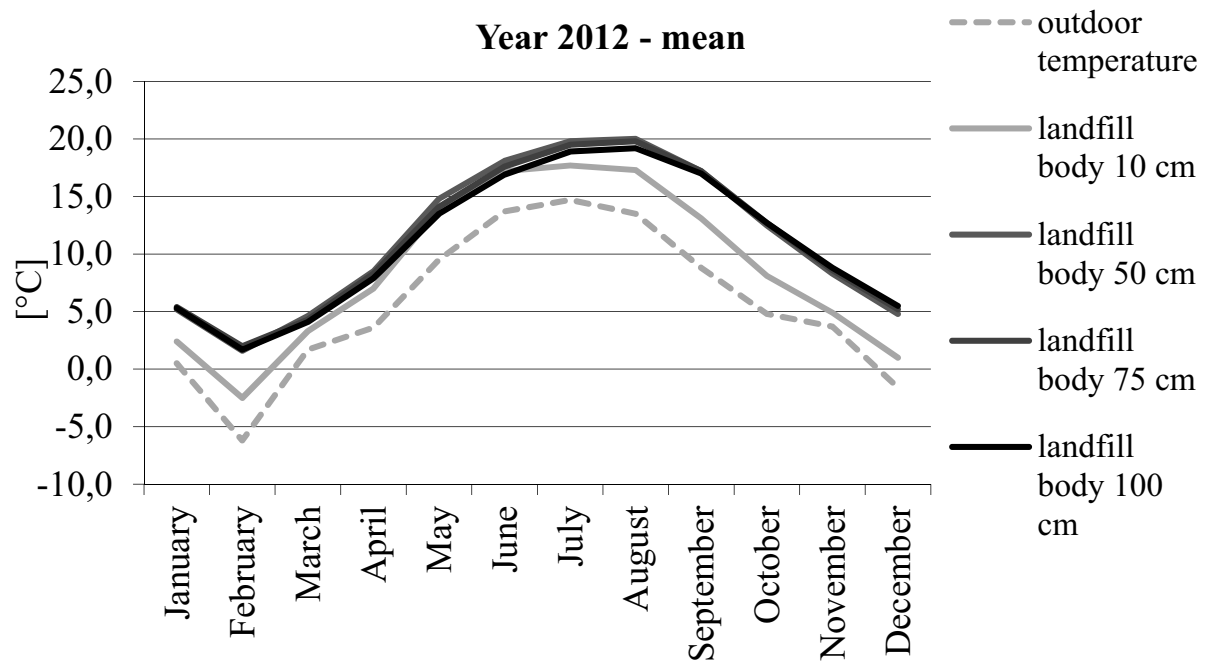

Fig. 3. The course of mean monthly temperatures in the period January-December 2012.

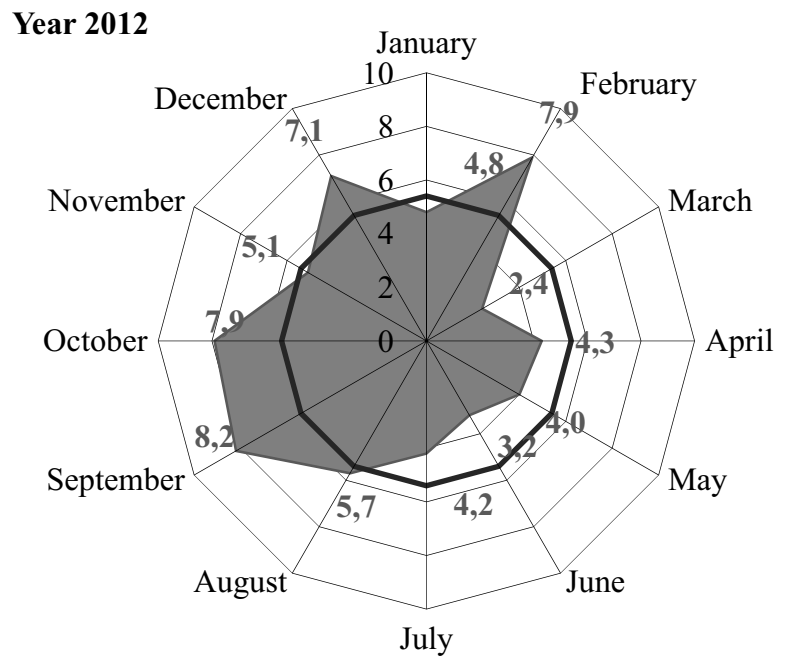

$\square$ difference between outdoor temperature and temperature in landfill body $100 \mathrm{~cm}\left[{ }^{\circ} \mathrm{C}\right]$

口mean difference between outdoor temperature and temperature in landfill body $100 \mathrm{~cm}\left[{ }^{\circ} \mathrm{C}\right]$

Fig. 4. Differences among outdoor temperatures and temperatures at a depth of $100 \mathrm{~cm}$ in the landfill body in 2012 .
Fig. 5 shows the course of daily temperatures in the landfill body at specified depths and the course of outdoor temperatures for the period January-September 2013. Daily outdoor temperatures in the period January-September 2013 show greater temperature fluctuations than daily temperatures in the landfill body at depths of $50 \mathrm{~cm}, 75$, and $100 \mathrm{~cm}$. The highest daily temperature fluctuations in the monitored period concern outdoor temperatures from $-8^{\circ} \mathrm{C}$ on 11 February 2013 to $21.4^{\circ} \mathrm{C}$ on 22 June 2013 and temperatures at $10 \mathrm{~cm}$ depth of the landfill body (temperatures ranged from $-0.8^{\circ} \mathrm{C}$ on 18 January 2013 to $24.5^{\circ} \mathrm{C}$ on 21 June 2013). As shown in Fig. 5, daily temperatures in the landfill body at depths of $50 \mathrm{~cm}, 75 \mathrm{~cm}$, and $100 \mathrm{~cm}$ showed almost identical development for all three depths. No significant differences among measured temperatures were recorded in particular depths $(50 \mathrm{~cm}, 75 \mathrm{~cm}$, and 100 $\mathrm{cm})$.

Fig. 6 shows the development of mean monthly values of measured outdoor temperatures and temperatures at determined depths of the landfill body for the period January-September 2013. The lowest average values were recorded at monthly temperatures measured in February

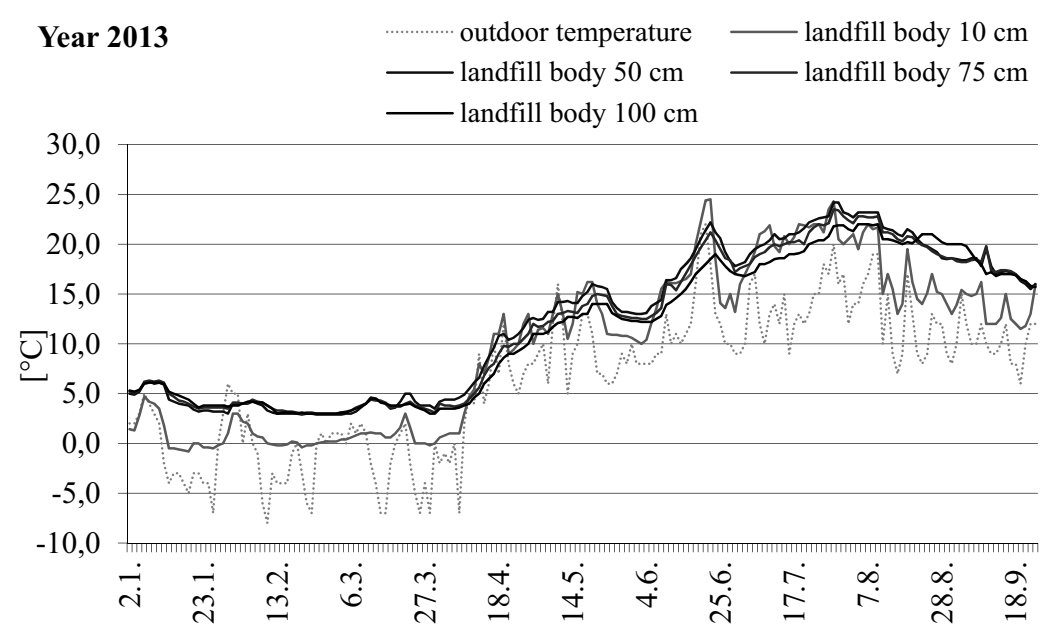

Fig. 5. The course of daily temperatures in the period January-September 2013. 


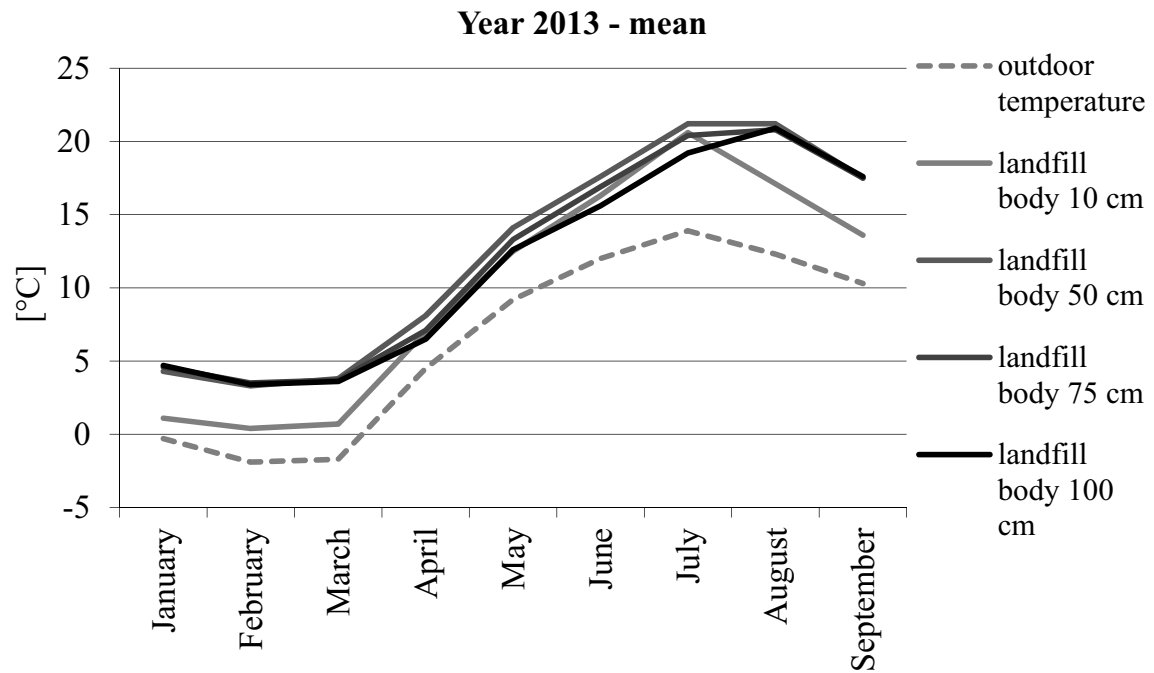

Fig. 6. The course of mean monthly temperatures in the period January-September 2013.

2013 (outdoor $-1.9^{\circ} \mathrm{C}$, at $10 \mathrm{~cm}$ depth $0.4^{\circ} \mathrm{C}$, at $50 \mathrm{~cm}$ depth $3.3^{\circ} \mathrm{C}$, at $75 \mathrm{~cm}$ depth $3.5^{\circ} \mathrm{C}$, and at $100 \mathrm{~cm}$ depth $3.4^{\circ} \mathrm{C}$ ). From March 2013 average monthly temperatures were gradually increasing; the highest average values were recorded in the period July-August (outdoor $13.9^{\circ} \mathrm{C}$ in July, at $10 \mathrm{~cm}$ depth $20.6^{\circ} \mathrm{C}$ in July and at $50 \mathrm{~cm}$ depth $21.2^{\circ} \mathrm{C}$ in August, at $75 \mathrm{~cm}$ depth $20.8^{\circ} \mathrm{C}$ in August, at $100 \mathrm{~cm}$ depth $20.9^{\circ} \mathrm{C}$ in August). In the period from August to September 2013 a decline in average monthly temperatures at all observed depths as well as in the outdoor temperature was recorded.

Higher average monthly temperatures for the period 2013 were measured in the landfill body at depths of $50 \mathrm{~cm}$, $75 \mathrm{~cm}$, and $100 \mathrm{~cm}$. The average outdoor temperature during the reporting period of 2013 was $6.5^{\circ} \mathrm{C}$, at $10 \mathrm{~cm}$ depth $9.9^{\circ} \mathrm{C}$, at $50 \mathrm{~cm}$ depth $12.3^{\circ} \mathrm{C}$, at $75 \mathrm{~cm}$ depth $12.0^{\circ} \mathrm{C}$, and $100 \mathrm{~cm}$ depth $11.5^{\circ} \mathrm{C}$.

\section{Year 2013}

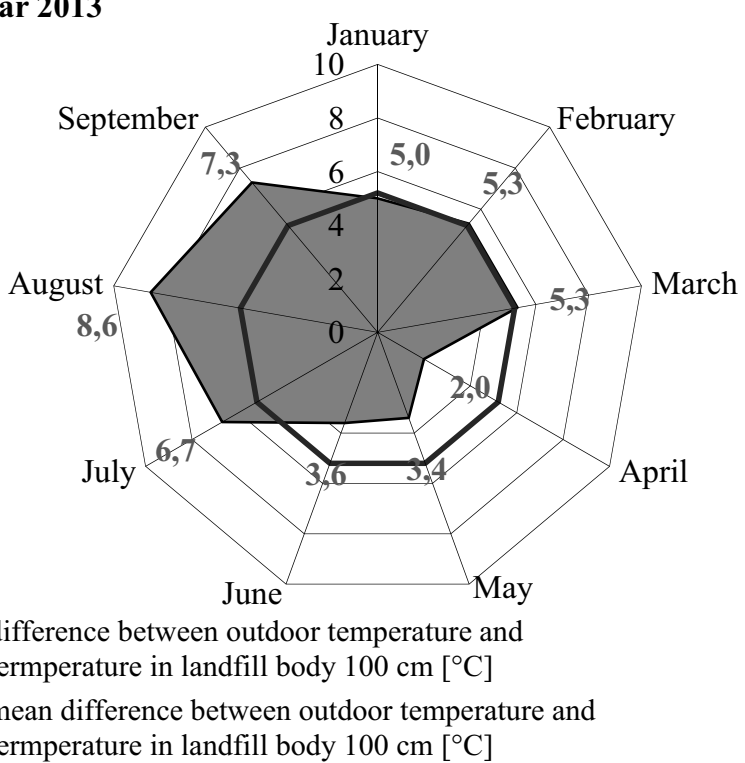

Fig. 7. Differences among outdoor temperatures and temperatures at $100 \mathrm{~cm}$ depth of the landfill body in 2013 .
Based on mean monthly temperature figures in the period January-September 2012 the differences between outdoor temperatures and temperatures at $100 \mathrm{~cm}$ depth of the landfill body in particular months were calculated. In addition, average annual value of the difference between outdoor temperature and temperature at $100 \mathrm{~cm}$ depth of the landfill body was determined. The obtained results were recorded in graph (Fig. 7).

The highest mean monthly value of the difference between outdoor temperature and the temperature at 100 $\mathrm{cm}$ depth in 2013 was determined for August $\left(8.6^{\circ} \mathrm{C}\right)$ and the lowest for April $\left(2.0^{\circ} \mathrm{C}\right)$. Average annual value of the difference between outdoor temperature and the temperature at $100 \mathrm{~cm}$ depth of the landfill body in 2013 amounted to $5.2^{\circ} \mathrm{C}$

\section{Conclusions}

This study was conducted to extensively investigate heat generation in landfill on a field scale, including the variation of temperatures. Data were collected at Štěpánovice landfill located in Czech Republic. Temperatures were determined over 21 months. The conclusions provided below are drawn based on long-term monitoring of temperatures within various depths of a municipal solid waste landfill:

- Mean annual value of the difference between outdoor temperature and temperature at a depth of $100 \mathrm{~cm}$ in the landfill body in 2012 amounted to $5.4^{\circ} \mathrm{C}$, and for the reporting period of 2013 it was $5.2^{\circ} \mathrm{C}$.

- No significant differences among measured temperatures were recorded at particular depths $(50 \mathrm{~cm}, 75 \mathrm{~cm}$ and $100 \mathrm{~cm}$ ).

- Mean temperature at the surface of the landfill within the whole reporting period was $3.2^{\circ} \mathrm{C}$ higher than ambient temperature (in the reporting period). This is explained due to the decomposition activity within the landfill site leading to the emission of warm gases from the site. 
- Temperature may be a significant factor affecting plant establishment and growth.

- The results provide new information for the estimation of the selection of plant species suitable for reclamation, which have higher chances to tolerate the unfavourable conditions they would be exposed to at a technically reclaimed landfill body.

\section{Acknowledgements}

This study was supported by the city of Klatovy and its technical services. We would like to express our great appreciation to the management of Štépánovice landfill. Namely, we are very grateful to Ing. Vladimír Král, Ph.D., and his colleagues for their assistance and their willingness to provide their time so generously.

\section{References}

1. HARD M., GAMPERLING O., HUBER-HUMER M. Comparison between lab- and full-scale applications of in situ aeration of an old landfill and assessment of long-term emission development after completion. Waste Manage. 33, (10), 2061, 2013.

2. WILLIAMS P.T. Waste Treatment and Disposal (second ed.) John Wiley \& Sons, Ltd., England, pp. 171-244, 2005.

3. VAVERKOVÁ M., ADAMCOVÁ D. Can Vegetation Indicate a Municipal Solid Waste Landfill's Impact on the Environment? Pol. J. Environ. Stud. 23, (2), 501, 2014.

4. WANG Y., PELKONEN M., KAILA J. Effects of temperature on the long-term behaviour of waste degradation, emissions and post-closure management based on landfill simulators. The Open Waste Manage. J. 5, 19, 2012.

5. CHRISTENSEN T.H., COSSU R., STEGMANN R. Landfilling of Waste: leachate, Elsevier Applied Science, pp. 656, 1992.

6. EL-FADEL M., FINDIKAKIS A.N., LECKIE J.O. Environmental impacts of solid waste landfilling. J Environ Manage. 50, (1), 1, 1997.
7. EJLERTSSON J., KARLSSON A., LAGERKVIST A., HJERTBERG T., SVENSSON B.H. Effects of co-disposal of wastes containing organic pollutants with municipal solid waste - a landfill simulation reactor study. Adv Environ Res. 7, (4), 949, 2003.

8. VAVILIN V.A., JONSSON S., EJLERTSSON J., SVENSSON B.H. Modelling MSW decomposition under landfill conditions considering hydrolytic and methanogenic inhibition. Biodegradation 17, (5), 389, 2006.

9. WOJCIECHOWSKA E., GAJEWSKA M., OBARSKAPEMPKOWIAK H. Treatment of Landfill Leachate by Constructed Wetlands: Three Case Studies. Pol. J. Environ. Stud. 19, (3), 643, 2010.

10. FILIPKOWSKA U. Effect of Recirculation Method on Quality of Landfill Leachate and Effectiveness of Biogas Production. Pol. J. Environ. Stud. 17, (2), 199, 2008.

11. TAŁAŁAJ I.A., DZIENIS L. Influence of Leachate on Quality of Underground Waters. Pol. J. Environ. Stud. 16, (1), 139, 2007.

12. FILIPKOWSKA U., AGOPSOWICZ M.H. Solids Waste Gas Recovery under Different Water Conditions. Pol. J. Environ. Stud. 13, (6), 663, 2004.

13. SŁOMCZYŃSKA B., SŁOMCZYŃSKI T. PhysicoChemical and Toxicological Characteristics of Leachates from MSW Landfills. Pol. J. Environ. Stud. 13, (6), 627, 2004.

14. KULIKOWSKA D., KLIMIUK E. Removal of Organics and Nitrogen from Municipal Landfill Leachate in TwoStage SBR Reactors. Pol. J. Environ. Stud. 13, (4), 389, 2004.

15. KOTOVICOVA J., TOMAN F., VAVERKOVÁ M., STEJSKAL B. Evaluation of waste landfills impact on the environment with the use of bioindicators. Pol. J. Environ. Stud. 20, (2), 371, 2011.

16. VAVERKOVÁ M., TOMAN F., ADAMCOVÁ D., KOTOVICOVÁ J. Verification of research of waste landfills impact on the environment with the use of bioindicators. Pol. J. Environ. Stud. 22, (2), 313, 2013.

17. VAVERKOVÁ M., ADAMCOVÁ D., TOMAN F., KOTOVICOVÁ J. Emission assessment at the Štěpánovice municipal landfill focusing on $\mathrm{CO}_{2}$ emissions. Environ Prot Eng. 2014, [In Press, Accepted Manuscript]. 